\title{
Identifikasi Status Gizi pada Remaja di Kota Banda Aceh
}

\author{
ZURNILA MARLI KESUMA, LATIFAH RAHAYU \\ Program Studi Statistika, Fakultas MIPA, Universitas Syiah Kuala \\ Jln. Syech Abdurrauf No.2 Kopelma Darussalam, Banda Aceh 23111 \\ Email: kesumaku@yahoo.com, latifahrahayus@gmail.com
}

\begin{abstract}
ABSTRAK
Masalah gizi pada remaja sangat penting untuk diidentifikasi mengingat remaja merupakan penerus bangsa. Identifikasi status gizi remaja khususnya dikota Banda Aceh yang menjadi ibu kota Provinsi Aceh sangat penting untuk peningkatan serta pengembangan usia produktif dimasa depan. Penelitian ini dilakukan di 29 sekolah yang tersebar pada sembilan kecamatan di Kota Banda Aceh dengan melibatkan tiga tingkatan sekolah yaitu Sekolah Dasar (SD), Sekolah Menengah Pertama (SMP), dan Sekolah Menengah Atas (SMA). Pemilihan sampel dengan menggunakan metode acak kelompok (cluster random sampling), dimana SD, SMP, SMA digunakan sebagai cluster. Hasil yang diperoleh adalah status gizi buruk yang terdeteksi pada remaja di kota Banda Aceh cukup kecil, yaitu $0.33 \%$, gizi kurang sebesar $3,48 \%$ dan gizi baik $65,17 \%$. Kasus kegemukan dan obesitas ditemukan masing masing sebesar $15,42 \%$ dan $15,59 \%$.
\end{abstract}

Kata Kunci: Gizi Buruk, Obesitas, Status Gizi.

\section{PENDAHULUAN}

Masa remaja merupakan masa pertumbuhan fisik paling kritis dalam siklus kehidupan manusia. Sebanyak 25\% tinggi badan saat dewasa diperoleh pada masa ini. Konsumsi yang tidak seimbang pada masa remaja menyebabkan tidak terpenuhinya zat-zat gizi untuk pertumbuhan sehingga terhambatnya pertumbuhan seperti usia menarche yang terlambat.

Batasan usia remaja menurut WHO adalah 12 sampai 24 tahun (WHO, 2012). Menurut Menteri Kesehatan RI tahun 2010, batas usia remaja adalah antara 10 sampai 19 tahun dan belum kawin. Sementara menurut BKKBN batasan usia remaja adalah $10-21$ tahun (Kemenkes, 2010).

Laporan terbaru dari Organisasi Kesehatan Dunia (WHO) menunjukkan bahwa 25\% populasi remaja di Wilayah Asia Tenggara menderita kekurangan gizi dan anemia, yang berdampak buruk pada kesehatan dan perkembangan mereka (WHO, 2008) dan bahwa antropometri adalah indikator yang baik untuk status gizi dan risiko kesehatan pada kelompok ini.

Di Indonesia masalah gizi utama pada remaja usia sekolah adalah defisiensi mikronutrien, khususnya anemia defisiensi zat besi, serta masalah malnutrisi, baik gizi kurang dan perawakan pendek maupun gizi lebih sampai obesitas dengan ko-morbiditasnya yang keduanya seringkali berkaitan dengan perilaku makan salah dan gaya hidup (IDAI, 2013).

Obesitas dan anemia merupakan dua hal yang rentan dihadapi remaja terkait permasalahan gizi. Maraknya restoran cepat saji yang menjamur sangat kontradiktif dengan fenomena obesitas yang telah menjadi epidemiologi global dan distorsi pada citra tubuh mempunyai kaitan dengan anemia terkait penyusutan bobot tubuh. Pemenuhan gizi dapat dilihat melalui status gizi individu (Pramitya A.A. dan Valentina T D, 2013).

Berdasarkan latar belakang di atas, maka dilakukan penelitian awal yang bertujuan untuk mengidentifikasi status gizi remaja di kota Banda Aceh yang diperoleh dengan survei berbasis sekolah. Distribusi terjadinya gizi buruk, gizi kurang, gemuk, obesitas dan gizi baik di setiap kecamatan dalam wilayah kota Banda Aceh juga dapat diperoleh dengan survey ini. 


\section{TINJAUAN PUSTAKA}

\section{Gizi Remaja}

Menurut Peraturan Menteri Kesehatan RI nomor 25 tahun 2014, rentang usia remaja adalah antara 10 sampai 18 tahun. Pada masa ini, seseorang akan mengalami pertumbuhan dan perkembangan yang pesat, mulai dari fisik, psikologis hingga intelektual. Kesehatan remaja di saat ini akan menjadi modal bagi perkembangan tingkat kesehatan generasi penerus di masa depan. Laporan singkat status gizi remaja ini, diharapkan dapat menjadi perhatian para orang tua dan guru di sekolah untuk memastikan kembang tumbuh remaja telah berjalan dengan baik.

Asupan zat gizi merupakan suatu hal yang penting guna memperoleh energi dalam melakukan kegiatan sehari-hari. Kekurangan asupan zat gizi dapat menyebabkan seseorang mengalami akibat buruk pada tubuh seperti menurunnya pertahanan tubuh terhadap penyakit, berkurangnya kemampuan fisik, menurunnya berat badan, muka pucat, kurang bersemangat, kurang motivasi, bereaksi lamban dan lain-lain (Wisnoe, 2005). Selain itu, kurangnya asupan zat gizi yang dikonsumsi seseorang juga akan mengakibatkan seseorang mengalami anemia, sesuai dengan hasil penelitian Wijayanti (2011) yang menyatakan bahwa terdapat hubungan yang signifikan antara asupan zat gizi dengan kejadian anemia.

Zat gizi minimal yang dibutuhkan oleh tubuh seseorang adalah karbohidrat, protein, lemak, dan vitamin. Menurut Beck (2011), karbohidrat atau yang disebut zat tenaga merupakan sumber energi utama bagi manusia. Kebutuhan karbohidrat menurut anjuran WHO (1997) adalah 65 - 75\% dari total konsumsi energi yang diutamakan berasal dari karbohidrat kompleks dan $10 \%$ berasal dari gula sederhana.

Selain karbohidrat, zat gizi lain yang dibutuhkan tubuh adalah protein, yang terdiri dari protein nabati dan protein hewani. Sumber protein hewani yang merupakan sumber protein yang baik dalam jumlah maupun mutu terdapat dalam bahan makanan seperti telur, susu, daging, unggas, ikan dan kerang. Sedangkan sumber protein nabati adalah kacang, kedelai dan hasil olahannya seperti tempe dan tahu. Kekurangan protein dapat menyebabkan gangguan pada asupan dan transportasi zat-zat gizi (Almatsier, 2009).

Seperti halnya karbohidrat dan protein, lemak juga merupakan sumber energi bagi tubuh. Fungsi utama lemak adalah menghasilkan energi yang diperlukan oleh tubuh, sebagai pembentuk struktur tubuh, mengatur proses yang berlangsung dalam tubuh secara langsung dan tidak langsung serta sebagai pembawa (carrier) vitamin yang larut dalam lemak. Sumber lemak diantaranya susu, minyak zaitun, minyak jagung, minyak kacang tanah, minyak ikan dan lain-lain. Menurut WHO (2008), kebutuhan lemak untuk anak usia 2-18 tahun adalah 25$35 \%$ dari kebutuhan energi total.

Zat gizi lain yang dibutuhkan tubuh adalah vitamin dan mineral. Zat gizi ini diperlukan untuk pertumbuhan dan perkembangan normal. Bila asupan vitamin dan mineral tidak mencukupi maka pertumbuhan akan terganggu dan menghasilkan sejumlah penyakit akibat defisiensi.

Menurut Irianto (2006), proporsi makanan sehat seimbang terdiri atas 60-65\% karbohidrat, $20 \%$ lemak, dan 15-20\% protein dari total kebutuhan atau keluaran energi per hari. Kebutuhan protein, lemak dan karbohidrat menurut WHO adalah protein sebanyak 10-15\% dari kebutuhan energi total,lemak 10-25\% dari kebutuhan energi total, dan karbohidrat 60$75 \%$ dari kebutuhan energi total atau sisa dari kebutuhan energi yang berasal dari protein dan lemak (Almatsier, 2009).

\section{Indeks Massa Tubuh (IMT)}

Indeks Massa Tubuh (IMT) merupakan salah satu metode yang digunakan untuk mengukur status gizi seseorang. IMT diukur berdasarkan antropometri, yaitu sebuah pengukuran dimensi tubuh yang terdiri dari umur (U), berat badan (BB), dan tinggi badan (TB). Berat badan ditimbang menggunakan timbangan digital yang memiliki presisi $0,1 \mathrm{~kg}$, tinggi badan diukur menggunakan alat ukur tinggi dengan presisi $0,1 \mathrm{~cm}$. Variabel BB dan TB remaja disajikan dalam bentuk tiga indeks antropometri, yaitu berat badan menurut umur $(\mathrm{BB} / \mathrm{U})$, tinggi badan menurut umur (TB/U), dan berat badan menurut tinggi badan (BB/TB) (KemenKes RI, 2015).IMT sendiri diperoleh dengan menggunakan persamaan (1), dimana berat badan dalam satuan kilogram $(\mathrm{kg})$ dan tinggi badan dalam satuan centimeter $(\mathrm{cm})$ (Depkes RI, 2005). 
$I M T=\frac{\text { Berat Badan }}{\text { Tinggi Badan }}$.

Kategori dan ambang batas status gizi remaja, yang dalam hal ini diukur dengan IMT, berdasarkan indeks antropometri menurut Keputusan Kementerian Kesehatan RI (2011) ditunjukkan oleh Tabel 1.

Tabel 1. Kategori dan Ambang Batas Status Gizi Remaja Berdasarkan Indeks Antropometri

\begin{tabular}{|l|l|c|}
\hline \multicolumn{1}{|c|}{ Indeks } & \multicolumn{1}{|c|}{ Kategori status gizi } & Ambang batas \\
\hline \multirow{4}{*}{$\begin{array}{l}\text { Indeks Massa Tubuh menurut } \\
\text { Umur }\end{array}$} & Sangat Kurus & $Z$-score< -3 \\
\cline { 2 - 3 } & Kurus & $-3 \leq Z$-score $<-2$ \\
\cline { 2 - 3 } & Normal & $-2 \leq Z$-score $\leq 1$ \\
\cline { 2 - 3 } & Gemuk & $1<Z$-score $\leq 2$ \\
\cline { 2 - 3 } & Obesitas & Z-score $>2$ \\
\hline
\end{tabular}

Sumber: Keputusan Kementerian Kesahatan RI (2011).

\section{METODOLOGI PENELITIAN}

Data

Penelitian ini dilakukan di 29 sekolah yang tersebar pada 9 kecamatan di Kota Banda Aceh. Pada Penelitian ini, digunakan tiga tingkatan sekolah yaitu Sekolah Dasar (SD), Sekolah Menengah Pertama (SMP), dan Sekolah Menengah Atas (SMA). Waktu pelaksanaan adalah pada tanggal $01-31$ Mei 2017.

\section{Teknik Pengambilan Sampel}

Teknik pengambilan sampel yang dilakukan adalah cluster random sampling, dimana SD, SMP, SMA digunakan sebagai cluster. Langkah yang dilakukan dalam memilih unit sampel ditetapkan sebagai berikut : List dari semua sekolah dan jumlah dari populasi untuk setiap cluster di setiap kecamatan diperoleh dari BPS. Selanjutnya dihitung frekuensi kumulatifnya. Untuk setiap cluster, dipilih 30 sekolah dengan menggunakan Probability Proportional to Size (PPS).

Perhitungan jumlah sampel dapat dilakukan dengan menggunakan software $R$ dengan library Epicalc (Chongsuvivatwong V, 2012) dengan memperhitungkan tingkat prevalensi kejadian. remaja kurus. Perintah yang digunakan adalah sebagai berikut:

n.for.survey ( $p$, delta, deff, alpha)

dimana $p$ merupakan prevalensi kejadian remaja kurus, delta adalah perbedaan antara estimasi prevalensi dan batas interval kepercayaan, deff adalah faktor penyesuaian untuk sampling cluster, dan alpha adalah peluang error tipe I. Jumlah sampel yang digunakan dalam survei ini dapat dihitung dengan:

n.for. $\operatorname{survey}(p=0.32$, delta $=0.12$, deff $=2$, alpha=0.01)

maka diperoleh ukuran sampel sebesar 200 untuk setiap cluster. Keseluruhan sampel adalah sebanyak 603 remaja.

\section{Prosedur Penelitian}

Langkah-langkah yang dilakukan selama penelitian adalah mengukur tinggi badan siswa sekolah menggunakan alat pengukur tinggi badan (stature meter) dan menimbang berat badan mereka menggunakan timbangan berat badan digital. 
Input dan Analisis Data

Data dalam penelitian ini diolah menggunakan software Microsoft Excel, SPSS dan R (epicalc).

\section{PEMBAHASAN}

Jumlah siswa/i SD, SMP dan SMA di Kota Banda Aceh yang ikut terlibat kegiatan Survei Status Gizi Remaja Kota Banda Aceh adalah sebanyak 603 responden.

Berikut status gizi siswa/i SD, SMP dan SMA di Kota Banda Aceh berdasarkan hasil Survei Status Gizi Remaja Kota Banda Aceh.

Tabe1 2. Status Gizi Remaja di Kota Banda Aceh

\begin{tabular}{|c|c|c|c|c|c|}
\hline & Gizi Buruk & Gizi Kurang & Gizi Baik & Gemuk & Obesitas \\
\hline Banyak Siswa & 2 & 21 & 393 & 93 & 94 \\
\hline \multicolumn{6}{|c|}{ Total Responden } \\
\hline
\end{tabular}

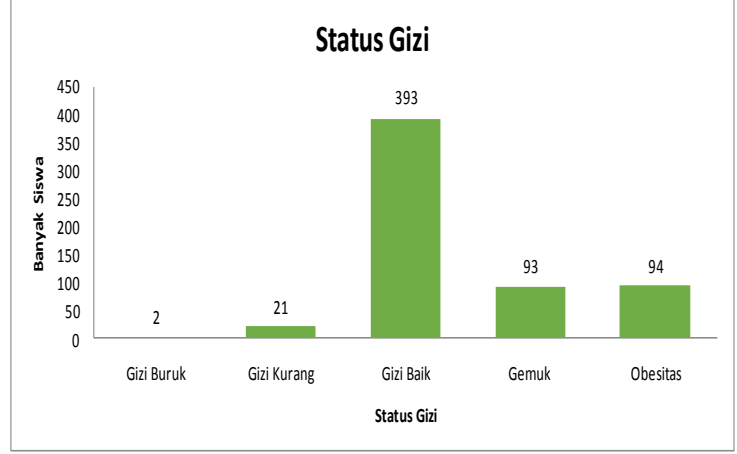

(a)

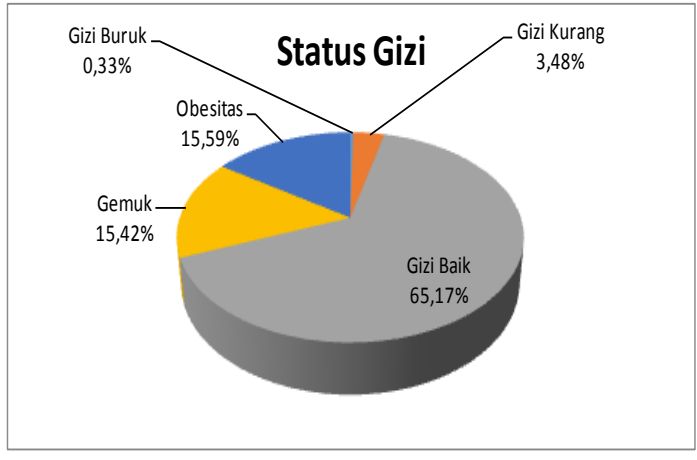

(b)

Gambar 1. (a) Status Gizi Remaja di Kota Banda Aceh berdasarkan jumlah siswa (b) Status Gizi Remaja di Kota Banda Aceh berdasarkan persentase

Tabel 3. Status Gizi Remaja untuk setiap Kecamatan di Kota Banda Aceh

\begin{tabular}{|l|c|c|c|c|c|}
\hline \multicolumn{1}{|c|}{ Kecamatan } & Gizi Buruk & Gizi Kurang & Gizi Baik & gemuk & obesitas \\
\hline Ulee Kareng & 1 & 1 & 39 & 9 & 5 \\
\hline Banda Raya & 0 & 2 & 43 & 13 & 13 \\
\hline Meuraxa & 0 & 2 & 29 & 12 & 12 \\
\hline Lueng Bata & 0 & 1 & 43 & 11 & 9 \\
\hline Kuta Raja & 0 & 2 & 35 & 11 & 15 \\
\hline Jaya Baru & 0 & 3 & 45 & 9 & 9 \\
\hline Kuta Alam & 0 & 6 & 76 & 17 & 15 \\
\hline Baiturrahman & 0 & 1 & 49 & 7 & 8 \\
\hline Syiah Kuala & 1 & 3 & 34 & 4 & 8 \\
\hline Total & 2 & 21 & 393 & 93 & 94 \\
\hline Total Responden & & & & 603 \\
\hline
\end{tabular}


Dari Tabel 2 dan Gambar 1 (a) dapat dilihat bahwa terdapat 2 remaja dengan status gizi buruk, 21 remaja gizi kurang, 393 remaja gizi baik, 93 remaja gemuk dan 94 remaja tergolong obesitas. Pada Gambar 1 (b) secara keseluruhan dapat dilihat pada diagram lingkaran, bahwa $0,33 \%$ dengan status gizi buruk, 3,48\% gizi kurang, 65,17\% gizi baik, $15,42 \%$ gemuk dan $15,59 \%$ dengan status obesitas.

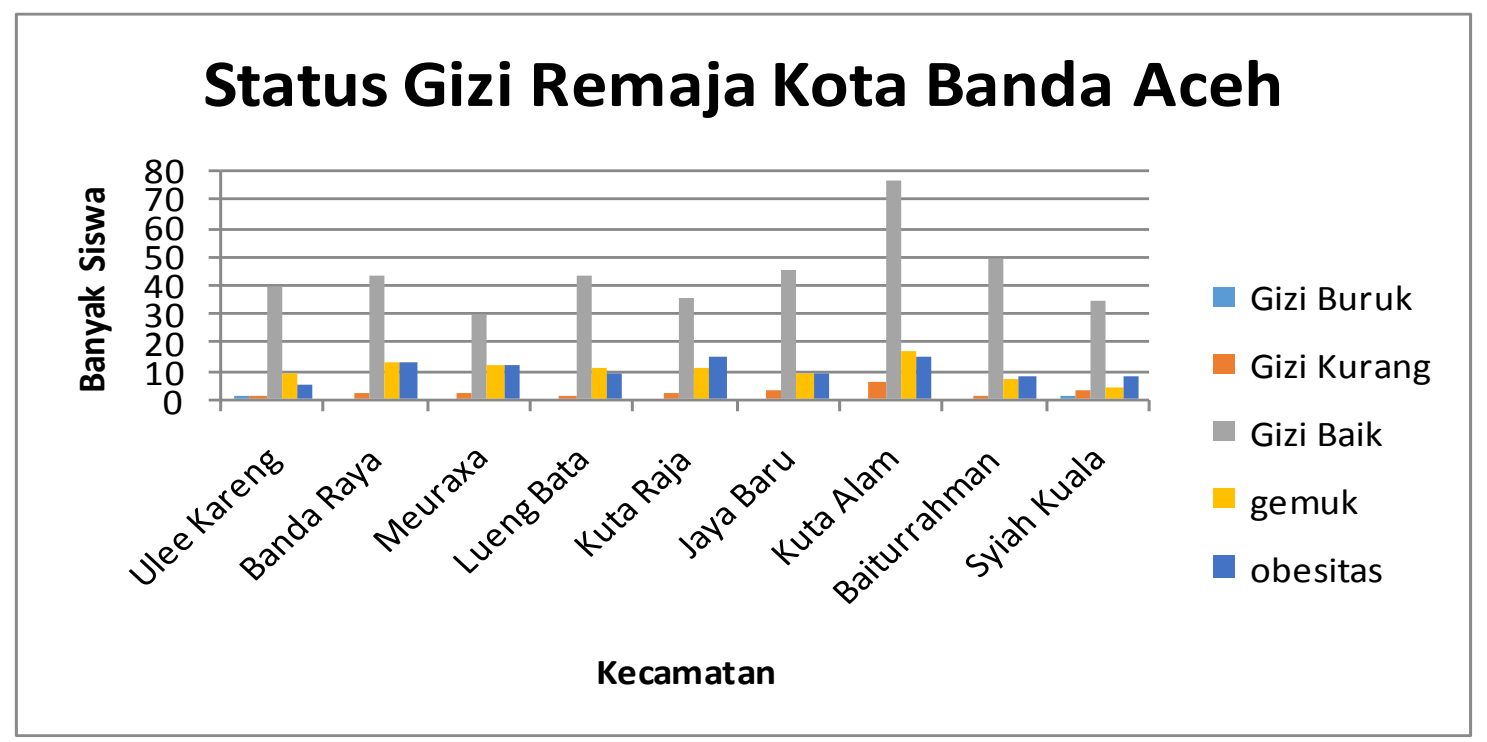

Gambar 2. Status Gizi Remaja untuk setiap Kecamatan di Kota Banda Aceh Berdasarkan Jumlah Siswa

Dari Tabel 3 dan Gambar 2 dapat dilihat bahwa status gizi buruk terdeteksi pada kecamatan Ulee Kareng dan Syiah Kuala masing-masing berjumlah 1 orang. Di samping itu, Gizi kurang tertinggi terdeteksi pada kecamatan Kuta Alam, Gizi Baik tertinggi terdeteksi pada kecamatan Kuta Alam, status gemuk tertinggi terdeteksi pada kecamatan Kuta Alam dan status obesitas terrtinggi terdeteksi pada kecamatan Kuta Alam dan Kuta Raja.

Gambar 3 menunjukkan secara keseluruhan Status Gizi Remaja untuk setiap Kecamatan di Kota Banda Aceh Berdasarkan Persentase. 


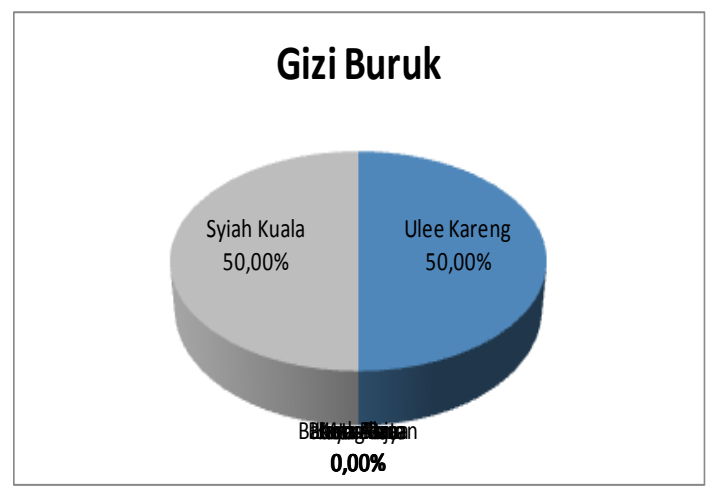

(a)

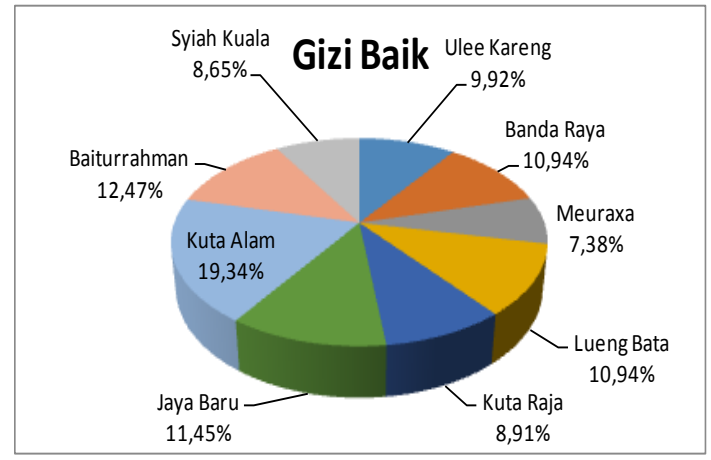

(c)

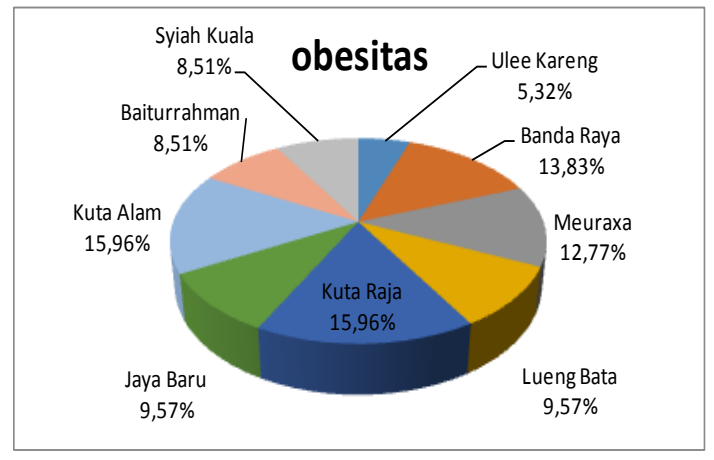

(e)

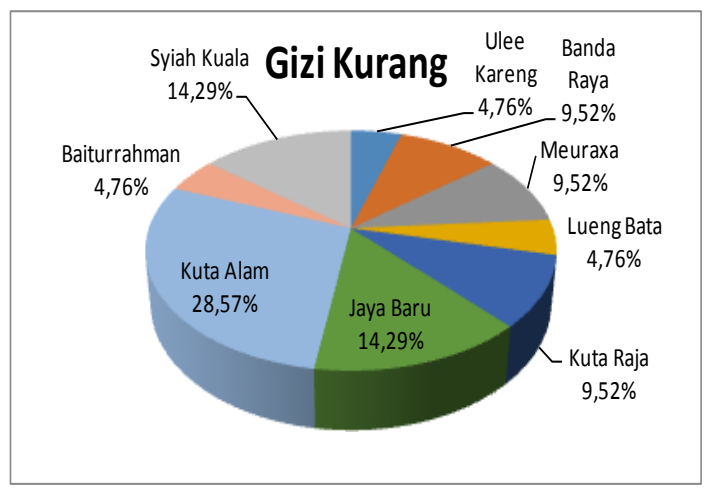

(b)

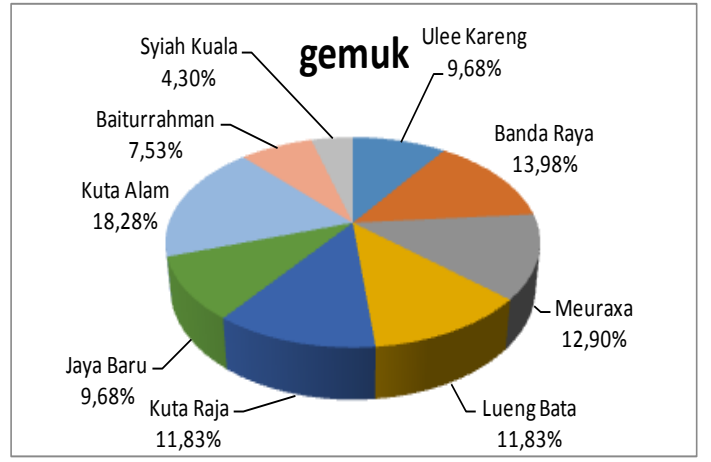

(d)

Gambar 3. (a), (b), (c), (d), (e) Status Gizi Remaja untuk setiap Kecamatan di Kota Banda Aceh Berdasarkan Persentase

\section{KESIMPULAN}

Analisa deskriptif yang diperoleh dalam survei status gizi remaja di Kota Banda Aceh menunjukkan bahwa walaupun secara umum berstatus gizi baik (65,17\%), masih terdapat 0,33\% remaja dengan status gizi buruk, 3,48\% gizi kurang, 15,42\% remaja gemuk dan 15,59\% remaja yang tergolong obesitas. Berdasarkan wilayah kecamatan di kota Banda Aceh, remaja dengan gizi buruk terdeteksi pada kecamatan Ulee Kareng dan Syiah Kuala Gizi kurang tertinggi terdeteksi pada kecamatan Kuta Alam, dan remaja dengan obesitas terrtinggi terdeteksi pada kecamatan Kuta Alam dan Kuta Raja.

\section{DAFTAR PUSTAKA}

Allen, M. L., et al. 2007. Adolescent participation in preventive health behaviors, physical activity, and nutrition: Differences across immigrant generations for Asians and Latinos compared with whites. American Journal of Public Health Vol 97(2), 337-343. 
Chongsuvivatwong V, 2012. "Analysis of epidemiological data using R and Epicalc" Book unit, Faculty of Medicine, Prince of Songkla Univesity.

Choudhary, S., Mishra, C.P., \& Shukla, K.P. 2010. Dietary pattern and nutrition related knowledge of rural adolescent girls. Indian J.Prev.Soc.Med, Vol 41(3), 207-2015.

Dinas kesehatan Aceh. 2012. Profil Kesehatan Provinsi Aceh Tahun 2012. Dinas kesehatan, Aceh.

Fatmah. 2010. Pengalaman negara lain dalam perbaikan gizi. Majalah Kedokteran Indonesia, Vol 60(2), 55-59.

IDAI (Ikatan Dokter Anak Indonesia). 2013. Gizi pada remaja. http://idai.or.id/ diunduh tanggal 24 April 2015.

Kementrian Kesehatan, Jakarta. 2010. Profil kesehatan Indonesia. Kementrian Kesehatan, Jakarta

World Health Organization. 2012. Indonesia Health Profile.Mother and Child Health. World Health Organization, Indonesia. 